\title{
DISPARITAS WILAYAH ANTAR KECAMATAN DI KABUPATEN SLEMAN
}

\author{
Ihsan Yoga Triyanto ${ }^{1}$, Yeremias T. Keban ${ }^{2}$ \\ ${ }^{1,2}$ Magister Perencanaan Wilayah dan Kota UGM \\ 1ihsantriyanto@gmail.com, ${ }^{2}$ kebanjeremy@gmail.com
}

\begin{abstract}
The process of economic development in Sleman Regency to result in economic growth that is marked by an increase in GDP per capita in this regency. However, the rate of economic growth and GDP per capita in each sub-regency has a different value, thus causing disparity between regions. The purposes of this study are: (1) to describe the regional disparity problem among sub-regencies in Sleman Regency in period of 2008-2016, (2) to determine the factors influencing that regional disparity level. To achieve the purposes, the data used are secondary data of 2008-2016 obtained from the BPS (The Central Bureau of Statistics), and the methods used are Williamson Index, panel data regression, and descriptive analysis. The findings of the study are (1) the regional disparity among sub-regencies in Sleman Regency tends to decrease during the observation period from 2008 to 2016. Williamson Index showed the moderate level of disparity with mean of index value is 0.3986 , (2) the most influential factors on the regional disparity are number of health facilities and tertiary sector contribution. The results of this study hopefully will provide useful information for the local government of Sleman Regency to design regional or sectoral development policy and is expected to contribute to further research on issues of regional development.
\end{abstract}

Keywords: panel data, regional disparity, Williamson Index

Abstraksi. Proses pembangunan ekonomi di Kabupaten Sleman menghasilkan pertumbuhan ekonomi yang ditandai dengan peningkatan PDRB per kapita di kabupaten ini. Namun, tingkat pertumbuhan ekonomi dan PDRB per kapita di setiap kecamatan memiliki nilai yang berbeda, sehingga menyebabkan kesenjangan antar wilayah. Tujuan dari penelitian ini adalah: (1) untuk mendeskripsikan masalah disparitas wilayah antar kecamatan di Kabupaten Sleman pada periode 2008-2016, (2) untuk mengetahui faktor-faktor yang mempengaruhi tingkat disparitas daerah tersebut. Untuk mencapai tujuan tersebut, data yang digunakan adalah data sekunder periode 2008-2016 yang diperoleh dari BPS, dan metode yang digunakan adalah Indeks Williamson, regresi data panel, dan analisis deskriptif. Temuan dari penelitian ini adalah (1) disparitas wilayah antar kecamatan di Kabupaten Sleman cenderung menurun selama periode pengamatan tahun 2008-2016. Indeks Williamson menunjukkan tingkat disparitas sedang dengan rata-rata nilai indeks 0,3986, (2) faktor yang paling berpengaruh terhadap disparitas wilayah adalah jumlah fasilitas kesehatan dan kontribusi sektor tersier. Hasil penelitian ini diharapkan akan memberikan informasi yang berguna bagi pemerintah daerah, khususnya Kabupaten Sleman untuk merancang kebijakan pembangunan regional atau sektoral dan diharapkan dapat berkontribusi untuk penelitian lebih lanjut tentang isu-isu pembangunan daerah.

Kata kunci: data panel, disparitas wilayah, Indeks Williamson 


\section{PENDAHULUAN}

Melalui pendekatan perencanaan ekonomi wilayah (regional economic approach), perencanaan pembangunan dan tata ruang diarahkan untuk mencapai tujuan sosial dan ekonomi secara luas, terutama mengenai ketimpangan wilayah di bidang kesejahteraan, ketenagakerjaan, serta kondisi sosial. Menurut Todaro (2000), tujuan pembangunan ekonomi secara multidimensional adalah menciptakan pertumbuhan dan perubahan struktur ekonomi, perubahan sosial, mengurangi atau menghapuskan kemiskinan, mengurangi ketimpangan atau disparitas, dan pengangguran. Salah satu indikator keberhasilan pembangunan ditunjukkan oleh pertumbuhan ekonomi dan berkurangnya ketimpangan baik di dalam distribusi pendapatan penduduk maupun antar wilayah. Berbagai masalah timbul dalam kaitan dengan pertumbuhan dan pembangunan ekonomi wilayah, dan terus mendorong perkembangan konsepkonsep pertumbuhan ekonomi wilayah.

Sebagian besar pemerintah daerah hingga saat ini masih menghadapi permasalahan pemerataan pembangunan. Permasalahan tersebut tidak hanya terkait dengan kesenjangan hasil-hasilnya, misalnya dalam hal pendapatan per kapita, tetapi juga kesenjangan dalam proses distribusinya. Bukan pula semata-mata berupa kesenjangan antar wilayah, akan tetapi juga berupa kesenjangan ekonomi dalam lapisan masyarakat. Ketimpangan wilayah di Indonesia pada periode otonomi daerah yang ditunjukkan dengan Indeks Gini tidak turun secara signifikan melainkan sempat naik (Agusta, 2014). Sumber ketimpangan tersebut salah satunya adalah karena pembagian keuangan pusat-daerah didasarkan kontribusi daerah dalam GDP.
Disparitas merupakan divergensi atau ketidaksetaraan karakter, fenomena atau proses, identifikasi dan perbandingan yang rasional secara kognitif, psikologis, sosial, ekonomi, politik, dan lain sebagainya (Kutscherauer et.al., 2010). Sementara itu disparitas wilayah berarti divergensi atau ketidaksetaraan karakter, fenomena atau proses yang dimiliki oleh suatu wilayah spesifik dan terjadi setidaknya dalam dua entitas struktur teritorial. Ketimpangan wilayah biasanya menyangkut perbedaan kecenderungan pembangunan masyarakat yang mengakibatkan munculnya ketimpangan pembangunan. Aspek sosial beserta bagian-bagiannya, termasuk fenomena dan proses yang terjadi apabila dikembangkan secara tidak merata akan menghasilkan ketidaksetaraan atau kesenjangan.

Kabupaten Sleman, yang terdiri dari 17 kecamatan, merupakan wilayah yang memiliki kinerja ekonomi yang relatif baik dibandingkan dengan kota/kabupaten lainnya di Daerah Istimewa Yogyakarta (DIY). Berdasarkan data Badan Pusat Statistik (2018), pada tahun 2017 Kabupaten Sleman memiliki angka laju pertumbuhan tertinggi kedua setelah Kabupaten Kulon Progo, yaitu sebesar $5,35 \%$. Dari pertumbuhan tersebut, Kabupaten Sleman memiliki kontribusi tertinggi dalam pembentukan ekonomi Provinsi DIY, yaitu sebesar 33,60 \%. Ditinjau dari PDRB per kapita, antara tahun 2013 hingga 2017 PDRB per kapita Kabupaten Sleman juga terus mengalami kenaikan, yaitu berturut-turut 24,78 Juta Rupiah, 26,78 Juta Rupiah, 28,97 Juta Rupiah, 31,29 Juta Rupiah, dan 33,59 Juta Rupiah. Nilai PDRB per kapita tersebut menduduki urutan terbesar kedua di DIY setelah Kota Yogyakarta. 
Meskipun kondisi ekonomi Kabupaten Sleman relatif tinggi dibandingkan kabupaten lainnya di Provinsi DIY, terdapat hal yang masih perlu menjadi perhatian, yaitu apakah pertumbuhan ekonomi yang tinggi tersebut dapat dinikmati oleh seluruh masyarakat. Devi (2018) mengemukakan bahwa tingginya PDRB per kapita belum dapat merepresentasikan kondisi kesejahteraan masyarakat secara riil karena adanya kemungkinan nilai PDRB yang tinggi tersebut hanya dimiliki oleh sebagian kecil masyarakat.

Permasalahan tentang adanya indikasi disparitas wilayah yang terjadi di wilayah Kabupaten Sleman perlu dikaji lebih mendalam. Mengacu pada penelitian mengenai disparitas di Kabupaten Sleman yang pernah dilakukan oleh Devi (2018), kajian ini dimaksudkan untuk mengetahui lebih jauh mengenai disparitas di Kabupaten Sleman dengan menggunakan rentang data yang lebih luas, yaitu antara 2008-2016. Salah satu metode untuk mengukur tingkat ketimpangan pembangunan antar wilayah adalah menggunakan Indeks Williamson. Istilah Indeks Williamson munsul sebagai penghargaan kepada Jeffrey G. Williamson yang pada awalnya menggunakan teknik ini untuk mengukur ketimpangan pembangunan antar wilayah. Meskipun indeks ini memiliki beberapa kelemahan, antara lain sensitif terhadap definisi wilayah yang digunakan dalam perhitungan, namun indeks ini lazim digunakan dalam mengukur ketimpangan antar wilayah (Sjafrizal, 2008).

Berbeda dengan Rasio Gini yang lazim digunakan untuk mengukur distribusi pendapatan, Indeks Williamson menggunakan Produk Domestik Regional Bruto (PDRB) per kapita sebagai data dasar, karena yang diperbandingkan adalah tingkat pembangunan antar wilayah dan bukan tingkat kemakmuran antar kelompok. Pengukuran indeks ini didasarkan pada variasi hasil-hasil pembangunan ekonomi antar wilayah yang berupa besaran PDRB. Semakin besar nilai indeks yang menunjukkan variasi produksi ekonomi antar wilayah, semakin besar pula tingkat perbedaan ekonomi masing-masing wilayah dengan rata-ratanya, sebaliknya semakin kecil nilainya maka tingkat pemerataannya semakin baik. Nilai indeks 0 menunjukkan tidak ada ketimpangan ekonomi antar wilayah, sedangkan semakin besar nilai indeks menunjukkan semakin besarnya ketimpangan ekonomi antar wilayah.

Penelitian ini juga dikembangkan dengan mengkaji faktor-faktor yang berpengaruh terhadap kondisi disparitas di Kabupaten Sleman. Faktor-faktor yang berpengaruh penting diketahui sebagai dasar penyusunan strategi atau skenario penanganan disparitas dalam kerangka pembangunan dan perencanaan tata ruang. Kutscherauer et.al (2010) berpendapat bahwa kajian mengenai disparitas bersifat rumit sehingga tidak hanya terbatas pada kajian ekonomi melainkan perlu memperluas dimensi kajian dengan melibatkan aspek sosial, teritorial, politik dan administrasi, institusional, lanskaplingkungan, peradaban-infrastruktur, serta sosial-kawasan. Hal tersebut dikarenakan disparitas muncul karena banyak faktor. Secara ringkas, dimensi kajian disparitas dapat dikelompokkan dalam 3 ranah, yaitu ranah sosial, ekonomi, dan teritorial. Sedangkan menurut Sjafrizal (2008), beberapa faktor utama yang menyebabkan atau memicu terjadinya disparitas wilayah adalah faktor geografis, historis, politis, kebijakan, administratif, sosial, dan 
ekonomi. Di Kabupaten Sleman, kajian mengenai faktor-faktor yang berpengaruh terhadap disparitas tersebut masih terbatas.

Di wilayah lain, penelitian mengenai faktor-faktor disparitas pernah dilakukan antara lain oleh Azwar, dkk (2013). Dengan metode linear equation (Verdoorn's Coefficient), faktor-faktor yang diuji adalah PDRB perkapita, lokasi konsentrasi aktivitas ekonomi, Indeks Pembangunan Manusia, produktivitas tenaga kerja, alokasi investasi publik, serta aksesibilitas. Sementara itu, Darzal (2016) dan Baransano, dkk (2016) melakukan analisis faktor disparitas menggunakan metode regresi data panel. Darzal (2016) melakukan penelitian dengan menggunakan variabel pengeluaran pemerintah, tingkat partisipasi angkatan kerja, serta sarana dan prasarana transportasi sebagai faktor yang dianggap berpengaruh, sedangkan varibael yang digunakan oleh Baransano, dkk (2016) adalah PDRB perkapita, jumlah penduduk, alokasi pendanaan, serta Indeks Pembangunan Manusia. Sedangkan penelitian mengenai disparitas wilayah di negara China oleh Wang (2016) dilakukan melalui analisis regresi terhadap faktor pengeluaran pemerintah, level infrastruktur, urbanisasi, dan pendidikan.

\section{METODE PENELITIAN}

Pendekatan yang digunakan dalam penelitian ini adalah melalui metode deduktif kuantitatif. Sesuai dengan masalah dan tujuan penelitian, maka metode penelitian ini disajikan dengan bentuk analisis deskriptif kuantitatif. Unit amatan penelitian ini meliputi variabel terikat yaitu disparitas wilayah yang diukur dengan Indeks Williamson, dan variabel bebas yaitu faktor-faktor yang secara teori mempengaruhi disparitas wilayah. Unit analisis dalam penelitian ini meliputi 17 kecamatan yang ada di Kabupaten Sleman.

\section{Sumber Data dan Variabel}

Metode pengumpulan data dilakukan dengan mengumpulkan data sekunder, yaitu melakukan studi kepustakaan dari publikasi data-data statistik BPS, yaitu Kabupaten Sleman dalam Angka dan Kecamatan dalam Angka, periode tahun 2008 hingga 2016. Data-data yang digunakan untuk mendeskripsikan disparitas wilayah meliputi PDRB per kapita kecamatan, PDRB per kapita kabupaten, jumlah penduduk kecamatan, dan jumlah penduduk kabupaten. Datadata yang digunakan untuk mengidentifikasi faktor-faktor yang mempengaruhi disparitas wilayah adalah jumlah fasilitas kesehatan, persentase KK tidak miskin, pertumbuhan ekonomi, persentase kontribusi sektor tersier, persentase angkatan kerja, kepadatan penduduk, persentase luas lahan terbangun, dan persentase luas lahan pertanian.

\section{Metode Analisis Data}

Perhitungan tingkat disparitas wilayah dilakukan dengan mengacu pada penelitian yang dilakukan oleh Baransano, dkk (2016), Darzal (2016), dan Devi (2018), yaitu analisis Indeks Williamson. Indeks tersebut digunakan untuk mengetahui ketimpangan pembangunan antar daerah, misalnya antar wilayah dalam suatu kabupaten, antar kabupaten/kota dalam suatu provinsi, maupun antar provinsi dalam negara (Muta'ali, 2015). Nilai indeks dalam penelitian ini ditentukan dengan cara membandingkan pendapatan per kapita 
kecamatan dengan rata-rata pendapatan per kapita kabupaten yang menjadi acuan. Nilai Indeks Williamson berkisar antara 0 sampai dengan $1 \quad(0<\mathrm{IW}<1)$, yang dalam hal ini semakin mendekati 0 maka ketimpangan semakin kecil, demikian juga sebaliknya, semakin mendekati 1 maka semakin besar ketimpangan yang terjadi.

Sama halnya dengan penelitian yang pernah dilakukan oleh Baransano, dkk (2016) dan Darzal (2016), untuk mengidentifikasi faktor penyebab disparitas wilayah antar kecamatan dilakukan melalui metode analisis regresi data panel. Analisis ini dijalankan menggunakan program Eviews. Metode analisis regresi data panel ini dipilih karena data dalam penelitian disparitas wilayah di Kabupaten Sleman ini merupakan gabungan data silang (cross section) dan data runtut waktu (time series). Data yang digunakan adalah data Indeks Williamson dan data faktor-faktor yang secara teori mempengaruhi disparitas wilayah, yaitu faktor ekonomi, sosial, dan teritorial. Pengolahan data ini terdiri dari beberapa langkah. Langkah pertama yaitu pengujian asumsi yang meliputi uji normalitas, uji autokorelasi, uji heteroskedastisitas, dan uji multikolinearitas. Langkah selanjutnya adalah analisis regresi sederhana data panel, serta langkah terakhir adalah pemilihan model regresi panel

\section{HASIL DAN PEMBAHASAN}

\section{A. Perkembangan Disparitas Wilayah di Kabupaten Sleman}

Hasil perhitungan indeks Williamson Kabupaten Sleman selama periode penelitian yaitu tahun 2008-2016 terlihat pada Tabel 1.
Tabel 1. Indeks Williamson abupaten Sleman Tahun 2008 - 2016

\begin{tabular}{cc}
\hline Tahun & Indeks Williamson \\
\hline 2008 & 0,4239 \\
2009 & 0,4154 \\
2010 & 0,4197 \\
2011 & 0,4349 \\
2012 & 0,4467 \\
2013 & 0,3868 \\
2014 & 0,4298 \\
2015 & 0,3151 \\
2016 & 0,3150 \\
\hline Rata-rata & 0,3986 \\
\hline
\end{tabular}

Sumber: hasil analisis

Rata-rata nilai indeks Williamson selama periode penelitian adalah 0,3986. Nilai tersebut menunjukkan bahwa disparitas wilayah di Kabupaten Sleman tergolong moderat/sedang. Berdasarkan tabel di atas, terlihat bahwa indeks Williamson Kabupaten Sleman memiliki kecenderungan menurun selama periode penelitian. Grafik peningkatan dan penurunan Indeks Williamson yang terjadi di Kabupaten Sleman selama tahun 2008 hingga 2016 dapat dilihat pada Gambar 1.

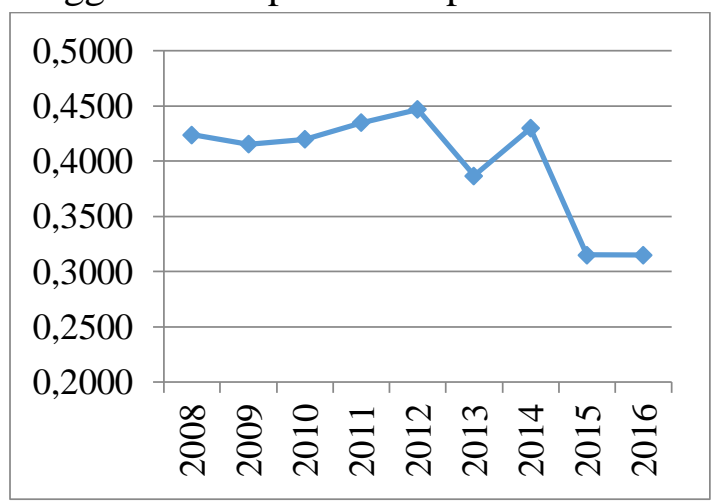

Gambar 1. Grafik Indeks Williamson

Kabupaten Sleman Tahun 2008-2016

Kecenderungan penurunan nilai indeks Williamson menunjukkan bahwa distribusi perekonomian antar kecamatan di Kabupaten Sleman semakin merata. Penelitian yang dilakukan oleh Devi (2018) menyatakan bahwa ketimpangan pendapatan antar kecamatan di Kabupaten 
Sleman selama 5 tahun pada periode 2010-2014 menunjukkan trend penurunan dan termasuk dalam kategori ketimpangan sedang. Dalam cakupan rentang waktu yang lebih panjang, yaitu 9 tahun (20082016), penelitian ini juga mengungkapkan hasil yang sama, yaitu terjadinya trend penurunan tingkat disparitas wilayah di Kabupaten Sleman. Menurut Devi (2018), terdapat hubungan yang kuat antara tingkat pertumbuhan ekonomi dan ketimpangan wilayah di Kabupaten Sleman pada periode 2010-2014, yaitu jika pertumbuhan ekonomi meningkat maka ketimpangannya akan menurun. Namun, Agusta (2014) menyatakan bahwa hubungan antara pertumbuhan ekonomi dan ketimpangan wilayah belum definitif, terutama pada tingkat global. Terdapat kasus di mana hubungan keduanya positif, namun kasus lainnya menunjukkan hubungan negatif, dan pada kasus berikutnya tidak muncul hubungan antar keduanya (Bhattacharya, dkk, dalam Agusta, 2014). Ketiadaan konsensus menandakan perlunya melihat hubungan kedua variabel ini pada tataran regional, atau sesuai dengan per kasus di daerah.

Adanya disparitas wilayah yang terjadi di Kabupaten Sleman menunjukkan adanya variasi distribusi pendapatan di tingkat kecamatan. Berdasarkan data BPS, beberapa kecamatan memiliki pendapatan per kapita yang relatif tinggi, sementara beberapa kecamatan lainnya memiliki pendapatan per kapita yang rendah. Kecamatan Sleman memiliki nilai PDRB per kapita paling tinggi dibandingkan kecamatan-kecamatan lainnya setiap tahunnya selama periode 2008-2016 dan selalu berada di atas nilai rata-rata PDRB per kapita kecamatan. Sedangkan kecamatan dengan nilai PDRB per kapita lebih rendah dari nilai rata-rata PDRB per kapita kecamatan setiap tahunnya selama periode 2008-2016 adalah Kecamatan Gamping, Mlati, Berbah, Kalasan, Ngemplak, Ngaglik, Tempel, dan Cangkringan. Dikaitkan dengan jumlah penduduknya, Kecamatan Mlati, Ngaglik, dan Gamping merupakan kecamatan dengan jumlah penduduk yang relatif tinggi dibandingkan dengan kecamatankecamatan lainnya sehingga memiliki nilai PDRB per kapita yang relatif tidak tinggi meskipun memiliki nilai kontribusi PDRB yang tinggi terhadap kabupaten.

\section{A. Analisis Statistik Faktor-faktor yang Berpengaruh terhadap Disparitas Wilayah}

Berikut akan disajikan deskripsi hasil pada langkah-langkah analisis data.

1) Pengujian asumsi

a. Uji Normalitas

Hasil uji normalitas nilai residual menunjukkan nilai Jarque-bera 1,783 dan signifikansi yaitu 0,409 sehingga signifikansi di atas 0,05 . Oleh karena itu dapat dikatakan bahwa data dalam penelitian ini berdistribusi normal.

b. Uji Autokorelasi

Hasil uji autokorelasi menunjukkan nilai signifikansi Obs*R-squared yaitu 0,0800 (nilainya lebih besar dari 0,05) sehingga tidak terdapat autokorelasi.

c. Uji Heteroskedastisitas

Hasil uji heteroskedastisitas menunjukkan diperoleh nilai signifikansi Obs*Rsquared yaitu 0,0744 (nilainya lebih besar dari 0,05) sehingga tidak terdapat heteroskedastisitas.

d. Uji Multikolinearitas

Nilai VIF pada setiap variabel bebas dalam pengujian ini sudah di bawah 10 sehingga tidak ada multikolinieritas.

2) Hasil analisis regresi 
Analisis regresi linear sederhana data panel dilakukan untuk mengidentifikasi pengaruh masing-masing faktor terhadap disparitas wilayah. Hasil analisis tersebut dapat dilihat pada Tabel 2.

Tabel 2. Hasil Analisis Regresi Linear Sederhana Data Panel

\begin{tabular}{|c|c|c|c|c|}
\hline \multicolumn{2}{|c|}{ Variabel } & \multirow{2}{*}{$\begin{array}{l}\text { Nilai sig } \\
0.013\end{array}$} & \multirow{2}{*}{$\begin{array}{l}\text { Keterangan } \\
\text { Berpengaruh }\end{array}$} & \multirow{2}{*}{$\begin{array}{l}\text { Koefisien } \\
0.004331\end{array}$} \\
\hline $\mathrm{X} 1$ & Jumlah fasilitas kesehatan & & & \\
\hline $\mathrm{X} 2$ & $\begin{array}{l}\text { persentase KK tidak } \\
\text { miskin }\end{array}$ & 0.2724 & $\begin{array}{l}\text { Tidak } \\
\text { berpengaruh }\end{array}$ & -0.000869 \\
\hline $\mathrm{X} 3$ & pertumbuhan ekonomi & 0,6021 & $\begin{array}{l}\text { Tidak } \\
\text { berpengaruh }\end{array}$ & -0.000397 \\
\hline $\mathrm{X} 4$ & $\begin{array}{l}\text { persentase kontribusi } \\
\text { sektor tersier }\end{array}$ & 0.0000 & Berpengaruh & 0,001892 \\
\hline X5 & persentase angkatan kerja & 0,4484 & $\begin{array}{l}\text { Tidak } \\
\text { berpengaruh }\end{array}$ & -0.000369 \\
\hline X6 & kepadatan penduduk & 0,3327 & $\begin{array}{l}\text { Tidak } \\
\text { berpengaruh }\end{array}$ & 0.0000051 \\
\hline $\mathrm{X} 7$ & $\begin{array}{l}\text { Persentase luas lahan } \\
\text { terbangun }\end{array}$ & 0,8824 & $\begin{array}{l}\text { Tidak } \\
\text { berpengaruh }\end{array}$ & 0.000233 \\
\hline $\mathrm{X} 8$ & $\begin{array}{l}\text { persentase luas lahan } \\
\text { pertanian }\end{array}$ & 0.6356 & $\begin{array}{l}\text { Tidak } \\
\text { berpengaruh }\end{array}$ & -0.000190 \\
\hline
\end{tabular}

Sumber: hasil analisis

Berdasarkan Tabel 2, dapat dilihat bahwa terdapat dua variabel yang memiliki nilai signifikansi kurang dari 0,05 , yaitu variabel jumlah fasilitas kesehatan dan persentase kontribusi sektor tersier, dengan koefisien yang relatif cukup kecil, yaitu berturut-turut mendekati nilai 0,004 dan 0,002.

Nilai koefisien regresi variabel jumlah fasilitas kesehatan yaitu 0,004 bernilai positif sehingga dapat dikatakan adanya pengaruh yang positif, artinya semakin meningkat jumlah fasilitas kesehatan, maka Indeks Williamson juga akan semakin meningkat. Nilai ini juga dapat diartikan adanya peningkatan Indeks Williamson sebesar 0,004 setiap kenaikan satu-satuan dari jumlah fasilitas kesehatan.

Nilai koefisien regresi variabel persentase kontribusi sektor tersier yaitu 0,002 sehingga dapat dikatakan adanya pengaruh yang positif, artinya semakin meningkat persentase kontribusi sektor tersier maka Indeks Williamson juga akan semakin meningkat. Nilai ini juga dapat diartikan adanya peningkatan disparitas sebesar 0,002 setiap kenaikan satu-satuan dari persentase kontribusi

sektor tersier.

Pada uji simultan (uji F) diperoleh nilai signifikansi 0,000 atau kurang dari 0,05 dan dapat dikatakan bahwa secara simultan (bersama-sama) terdapat pengaruh yang signifikan dari variabel independen secara bersama-sama terhadap variable dependen. Nilai $\mathrm{R}^{2}$ yang diperoleh adalah sebesar 0,2162, yang dapat diartikan bahwa variabel bebas secara bersama-sama mempengaruhi variabel terikat sebesar $21,62 \%$ dan sisanya dipengaruhi oleh variabel lainnya. 3). Pemilihan model regresi panel

Pemilihan model analisis data panel antara model fixed effect, common effect, 
dan random effect dilakukan melalui beberapa pengujian, yaitu uji Chow, uji Haussman, dan uji Lagrange Multiplier (LM). Berdasarkan hasil uji Chow, diperoleh nilai signifikansi 0,000 (sig<0,05), sehingga dapat diartikan bahwa model fixed effect lebih baik dari common effect. Sedangkan dari hasil uji Haussman diperoleh nilai signifikansi $0,3924(\mathrm{sig}>0,05)$ pada probabilitas nilai dari cross section random, yang memiliki arti bahwa model regresi data panel dengan metode random effect lebih baik daripada fixed effect. Sementara berdasarkan hasil uji Lagrange Multiplier (LM), diperoleh nilai signifikansi 0,000 $($ sig $<0,05)$ pada probabilitas nilai dari Breusch-Pagan, sehingga dapat diartikan bahwa model regresi data panel dengan metode random effect lebih baik daripada metode common effect. Dari ketiga pengujian tersebut, dapat disimpulkan bahwa model regresi data panel yang paling sesuai digunakan pada penelitian ini adalah metode random effect.

Hasil regresi yang diperoleh melalui metode random effect adalah 17 model regresi, artinya objek yang diteliti (kecamatan) dianggap memiliki karakteristik yang berbeda-beda. Perbedaan dengan metode fixed effect adalah pada metode random effect.

Hasil regresi yang diperoleh melalui metode random effect adalah 17 model regresi, artinya objek yang diteliti (kecamatan) dianggap memiliki karakteristik yang berbeda-beda. Perbedaan dengan metode fixed effect adalah pada metode random effect menggunakan nilai residual dalam perhitungan nilai konstan. Nilai residual ini yang diduga memiliki hubungan antarwaktu dan antarobjek.
Persamaan regresi data panel berganda dinyatakan oleh persamaan:

Yit $=$ Xit $\beta+\alpha+$ ui + eit

Di mana Yit menyatakan indeks Williamson, Xit faktor-faktor yang mempengaruhi, $\alpha$ adalah konstanta, dan ui adalah nilai residual untuk setiap kecamatan, dan cit menyatakan error.

Berdasarkan analisis statistik, faktor jumlah fasilitas kesehatan memiliki pengaruh positif yang signifikan terhadap terjadinya disparitas wilayah antar kecamatan di Kabupaten Sleman. Semakin tinggi jumlah fasilitas kesehatan, semakin tinggi pula disparitas wilayah yang terjadi. Fasilitas kesehatan yang dimaksud meliputi puskesmas, puskesmas pembantu, poliklinik, dan rumah sakit bersalin.

Berdasarkan data BPS, jumlah fasilitas kesehatan yang relatif tinggi pada akhir periode penelitian (tahun 2016) berada di empat kecamatan yang termasuk dalam tipologi wilayah berkembang cepat, yaitu Kecamatan Depok, Kalasan, Gamping, dan Mlati. Selain itu, terjadi kenaikan jumlah fasilitas kesehatan yang cukup signifikan di empat kecamatan tersebut selama periode 2008 hingga 2016 bila dibandingkan dengan kecamatankecamatan lain, sebagaimana disajikan pada Tabel 3. Secara spasial, kecamatankecamatan tersebut memiliki lokasi relatif dekat dengan Kota Yogyakarta dan memiliki wilayah yang termasuk dalam Kawasan Perkotaan Yogyakarta. Kawasan ini memiliki fungsi untuk melayani kegiatan skala yang relatif luas. Dengan demikian, kawasan ini memiliki ketersediaan fasilitas lengkap untuk mendukung fungsi tersebut.

Sedangkan kecamatan-kecamatan dengan jumlah fasilitas kesehatan yang relatif rendah pada tahun 2016 adalah 
Kecamatan Moyudan, Minggir, Seyegan, Berbah, dan Cangkringan. Kelima kecamatan tersebut dikategorikan dalam wilayah relatif tertinggal.

Tabel 3. Jumlah Fasilitas Kesehatan Tiap Kecamatan di Kabupaten Sleman Tahun 2008-2016

\begin{tabular}{lccccccccc}
\hline Kecamatan & $\mathbf{2 0 0 8}$ & $\mathbf{2 0 0 9}$ & $\mathbf{2 0 1 0}$ & $\mathbf{2 0 1 1}$ & $\mathbf{2 0 1 2}$ & $\mathbf{2 0 1 3}$ & $\mathbf{2 0 1 4}$ & $\mathbf{2 0 1 5}$ & $\mathbf{2 0 1 6}$ \\
\hline Moyudan & 7 & 8 & 6 & 7 & 7 & 7 & 7 & 7 & 7 \\
Minggir & 9 & 9 & 6 & 7 & 7 & 7 & 7 & 7 & 7 \\
Seyegan & 5 & 9 & 9 & 9 & 9 & 9 & 9 & 9 & 7 \\
Godean & 19 & 20 & 10 & 10 & 10 & 10 & 10 & 11 & 11 \\
Gamping & 14 & 14 & 15 & 17 & 17 & 14 & 14 & 14 & 18 \\
Mlati & 12 & 12 & 13 & 13 & 13 & 14 & 16 & 16 & 16 \\
Depok & 15 & 20 & 21 & 21 & 27 & 27 & 27 & 27 & 27 \\
Berbah & 6 & 7 & 5 & 5 & 5 & 5 & 5 & 7 & 7 \\
Prambanan & 10 & 10 & 10 & 10 & 10 & 10 & 10 & 10 & 10 \\
Kalasan & 11 & 11 & 14 & 18 & 18 & 19 & 19 & 19 & 19 \\
Ngemplak & 12 & 12 & 12 & 12 & 12 & 14 & 11 & 11 & 11 \\
Ngaglik & 12 & 12 & 12 & 12 & 12 & 10 & 11 & 11 & 11 \\
Sleman & 14 & 15 & 15 & 19 & 19 & 19 & 16 & 15 & 13 \\
Tempel & 13 & 13 & 13 & 13 & 13 & 12 & 10 & 10 & 9 \\
Turi & 8 & 8 & 10 & 11 & 11 & 11 & 11 & 11 & 11 \\
Pakem & 12 & 12 & 12 & 11 & 11 & 11 & 11 & 11 & 11 \\
Cangkringan & 6 & 6 & 6 & 6 & 7 & 6 & 6 & 6 & 6 \\
\hline
\end{tabular}

Penelitian mengenai pengaruh faktor jumlah fasilitas kesehatan terhadap disparitas wilayah juga pernah dilakukan oleh peneliti lain. Pratiwi (2011) menyatakan bahwa disparitas wilayah antar kecamatan antara lain dipengaruhi oleh jumlah fasilitas kesehatan. Adanya perbedaan jumlah fasilitas kesehatan yang signifikan antara satu kecamatan dengan kecamatan lainnya menyebabkan terjadinya disparitas wilayah. Sejalan dengan itu, Rahman (2009) mengungkapkan bahwa salah satu faktor utama yang mempengaruhi tingkat disparitas pembangunan antar wilayah adalah faktor sarana dan penciri perkotaan. Dengan demikian, intervensi kebijakan dalam bidang kesehatan menjadi salah satu hal yang penting dalam mengurangi disparitas antar wilayah (Azwar dkk, 2013).
Menurut Kutscherauer et.al (2010), fasilitas kesehatan merupakan salah satu komponen yang dikaji dalam infrastruktur sosial dalam rangka penilaian faktor disparitas dari aspek sosial. Dikemukakan pula bahwa infrastruktur sosial merupakan hal mendasar untuk menyediakan layanan dalam mempertahankan dan mengembangkan tenaga di suatu wilayah dan sarana untuk memenuhi kebutuhan dasar dan menjamin hak-hak dasar penduduk (hak untuk tinggal, untuk layanan kesehatan, untuk pendidikan). Dalam infrastruktur sosial tersebut, preferensi terbesar terletak pada faktor layanan kesehatan dan layanan sosial terkait dengan terjaminnya penduduk usia lanjut. Faktor ini diwakili oleh indikator jumlah dokter, jumlah tempat tidur klinis, serta jumlah kamar di fasilitas.

Aspek infrastruktur menjadi penting dalam melihat terjadinya disparitas 
wilayah. Terdapat korelasi yang positif antara tingkat perkembangan infrastruktur dengan pertumbuhan ekonomi wilayah (Wang, 2016). Pertumbuhan ekonomi yang bervariasi antar wilayah tersebut selanjutnya menyebabkan terjadinya kesenjangan.

Penelitian yang dilakukan oleh Rachmawati(2017) tidak mengungkapkan adanya pengaruh yang signifikan antara faktor sarana kesehatan terhadap disparitas wilayah di Daerah Istimewa Yogyakarta (DIY). Disparitas yang terjadi dalam lingkup wilayah DIY dipengaruhi secara signifikan oleh faktor jumlah UMKM, dan rasio pekerja non primer terhadap pekerja primer. Hal ini menunjukkan bahwa dalam lingkup yang lebih luas (yaitu DIY), di mana Kabupaten Sleman termasuk di dalamnya, jumlah fasilitas kesehatan tidak memiliki pengaruh terhadap disparitas wilayah.

Faktor persentase kontribusi sektor tersier juga memiliki pengaruh positif yang signifikan terhadap terjadinya disparitas wilayah antar kecamatan di Kabupaten Sleman. Semakin tinggi persentase kontribusi sektor tersier, semakin tinggi pula disparitas wilayah yang terjadi. Dilihat pada tingkat kabupaten, peranan sektor tersier dalam struktur perekonomian mengalami peningkatan selama periode tahun 20112016 yaitu dari 64,55 persen pada tahun 2011 menjadi 67,3 persen pada tahun 2016. Sektor tersier meliputi Perdagangan Besar dan Eceran, Reparasi Mobil dan Sepeda Motor, Transportasi dan Pergudangan, Penyediaan Akomodasi dan Makan Minum, Informasi dan Komunikasi, Jasa Keuangan dan Asuransi, Real Estate, Jasa Perusahaan, Administrasi Pemerintahan, Pertahanan dan Jaminan Sosial Wajib, Jasa
Pendidikan, Jasa Kesehatan dan Kegiatan Sosial, dan Jasa lainnya. Sedangkan kontribusi sektor primer dan sekunder mengalami penurunan pada periode yang sama, yakni masing-masing dari 9,21 persen menjadi 8,47 persen dan dari 26,25 persen menjadi 24,22 persen.

Empat kecamatan dengan kontribusi sektor tersier paling besar pada akhir periode (tahun 2016) berturut-turut adalah Kecamatan Sleman yaitu sebesar 84,75\%, diikuti oleh Kecamatan Depok sebesar 80,62\%, Kecamatan Mlati sebesar $71,46 \%$, dan Kecamatan Ngaglik sebesar $68,12 \%$. Namun apabila dilihat dari nilai rata-ratanya, Kecamatan Depok menempati urutan pertama yaitu sebesar 79,37\% diikuti Kecamatan Sleman sebesar 70,63\%, Kecamatan Mlati sebesar $65,28 \%$, dan Kecamatan Godean sebesar $60,15 \%$.

Persentase kontribusi sektor tersier tiap kecamatan selama periode 2008-2016 ditunjukkan pada Tabel 4.

Secara spasial, pertumbuhan kontribusi sektor tersier tidak membentuk pola yang spesifik. Beberapa angka pertumbuhan yang masuk kategori sedang berada di kecamatan-kecamatan yang termasuk wilayah berkembang cepat, seperti Kecamatan Kalasan, Kecamatan Gamping, dan Kecamatan Ngaglik. Ketiga kecamatan tersebut juga memiliki wilayah yang menjadi bagian dari aglomerasi Kawasan Perkotaan Yogyakarta. Namun terkait dengan hal tersebut, Kecamatan Depok justru memiliki angka pertumbuhan yang rendah meskipun kontribusinya justru paling tinggi. Hal ini dikarenakan karena kontribusi sektor tersier di Kecamatan Depok telah tinggi sejak dari tahun pengamatan dan relatif stabil pertumbuhannya selama rentang waktu pengamatan. Sementara itu, selain 
di Kecamatan Berbah, angka pertumbuhan yang tinggi justru terdapat di Kecamatan Turi dan Cangkringan di mana memiliki lokasi di pinggiran dan termasuk dalam kategori wilayah relatif tertinggal. Namun demikian, terdapat pula beberapa kecamatan lainnya yang secara lokasional termasuk di wilayah pinggiran memiliki angka pertumbuhan rendah seperti
Kecamatan Minggir, Seyegan, dan Prambanan. Fenomena di atas mengindikasikan adanya proses pergeseran struktur ekonomi di Kabupaten Sleman menuju ke sektor tersier. Akan tetapi, pertumbuhan lapangan-lapangan usaha di sektor tersier tersebut terjadi tidak merata.

Tabel 4. Persentase Kontribusi Sektor Tersier Tiap Kecamatan di Kabupaten Sleman

Tahun 2008-2016

\begin{tabular}{lrrrrrrrrrr}
\hline Kecamatan & $\mathbf{2 0 0 8}$ & $\mathbf{2 0 0 9}$ & $\mathbf{2 0 1 0}$ & $\mathbf{2 0 1 1}$ & $\mathbf{2 0 1 2}$ & $\mathbf{2 0 1 3}$ & $\mathbf{2 0 1 4}$ & $\mathbf{2 0 1 5}$ & $\mathbf{2 0 1 6}$ & $\begin{array}{c}\text { Rata- } \\
\text { rata }\end{array}$ \\
\hline Moyudan & 32,85 & 31,32 & 32,01 & 32,31 & 32,6 & 31,01 & 32,21 & 43,98 & 39,6 & 34,21 \\
Minggir & 41,36 & 42,39 & 43,00 & 42,62 & 43,07 & 42,85 & 44,05 & 43,55 & 39,57 & 42,50 \\
Seyegan & 39,17 & 40,72 & 40,76 & 39,58 & 39,64 & 39,06 & 40,29 & 44,77 & 41,14 & 40,57 \\
Godean & 58,47 & 58,66 & 58,44 & 58,85 & 58,52 & 58,77 & 59,82 & 66,51 & 63,29 & 60,15 \\
Gamping & 52,31 & 52,32 & 52,6 & 52,55 & 52,98 & 51,34 & 52,4 & 70,06 & 67,5 & 56,01 \\
Mlati & 63,26 & 62,38 & 63,02 & 63,11 & 63,18 & 63,24 & 64,19 & 73,72 & 71,46 & 65,28 \\
Depok & 77,38 & 78,31 & 78,54 & 78,56 & 79,61 & 79,45 & 80,2 & 81,64 & 80,62 & 79,37 \\
Berbah & 34,63 & 35,09 & 34,29 & 33,97 & 34,32 & 32,82 & 33,95 & 66,02 & 60,67 & 40,64 \\
Prambanan & 51,5 & 54,29 & 56,23 & 55,55 & 55,06 & 55,53 & 56,72 & 42,71 & 51,72 & 53,26 \\
Kalasan & 49,95 & 51,42 & 51,3 & 50,61 & 50,9 & 49,96 & 51,04 & 66,56 & 63,19 & 53,88 \\
Ngemplak & 54,06 & 54,84 & 55,29 & 53,75 & 54,13 & 53,46 & 54,6 & 68,02 & 62,28 & 56,71 \\
Ngaglik & 51,94 & 52,07 & 53,3 & 52,54 & 53,37 & 52,46 & 71,77 & 72,05 & 68,12 & 58,62 \\
Sleman & 69,3 & 69,59 & 69,41 & 69,75 & 71,27 & 70,82 & 42,79 & 88,03 & 84,75 & 70,63 \\
Tempel & 43,9 & 44,32 & 43,45 & 43,44 & 42,34 & 41,53 & 35,43 & 65,27 & 61,41 & 46,79 \\
Turi & 37,1 & 36,93 & 36,2 & 36,95 & 35,45 & 34,17 & 67,22 & 49,86 & 66,33 & 44,47 \\
Pakem & 61,81 & 63,53 & 52,6 & 65,81 & 66,43 & 67,19 & 41,47 & 33,21 & 64,26 & 57,37 \\
Cangkringan & 31,55 & 31,63 & 39,1 & 38,42 & 38,67 & 40,03 & 59,47 & 31,73 & 54,49 & 40,57 \\
\hline Rata-rata & 50,03 & 50,58 & 50,56 & 51,08 & 51,27 & 50,81 & 52,21 & 59,28 & 61,20 & 53,00 \\
kecamatan & & & & & & & &
\end{tabular}

Sumber: data BPS, diolah

Hal positif yang dapat diambil dari fenomena tersebut adalah adanya indikasi mulai terjadi proses pemerataan perkembangan wilayah di Kabupaten Sleman. Pertumbuhan lapangan-lapangan usaha sektor tersier yang identik dengan kegiatan-kegiatan perdagangan dan layanan jasa menunjukkan mulai berkembangnya pusat-pusat kegiatan di wilayah pinggiran Kabupaten Sleman. Pusat-pusat kegiatan baru tersebut, di masa mendatang diharapkan dapat menjadi faktor pendorong pemerataan pembangunan dan perkembangan wilayah
Kabupaten Sleman. Pada akhirnya, ketimpangan wilayah di Kabupaten Sleman dapat terus menurun. Hal tersebut sejalan dengan pernyataan Rachmawati (2017) bahwa transaksi dan transformasi ekonomi ke arah non primer merupakan bagian dari sistem produksi untuk mengelola sumber daya yang dimiliki oleh daerah.

\section{SIMPULAN}

Penelitian ini mengungkapkan temuan bahwa tingkat disparitas wilayah di Kabupaten Sleman secara umum berada 
dalam kategori sedang/moderat dengan kecenderungan menurun selama periode 9 tahun, yaitu tahun 2008 hingga 2016, dengan nilai rata-rata Indeks Williamson 0,3986 . Hal ini menunjukkan bahwa upaya-upaya yang dilakukan khususnya oleh pemerintah daerah Kabupaten Sleman untuk mengurangi disparitas wilayah cukup berhasil, meskipun belum mencapai kategori tingkat disparitas yang rendah.

Temuan lain yang diperoleh melalui penelitian ini adalah bahwa berdasarkan analisis statistik, faktor yang berpengaruh terhadap tingkat disparitas wilayah antar kecamatan di Kabupaten Sleman selama periode 2008-2016 adalah jumlah fasilitas kesehatan dan persentase kontribusi sektor tersier. Temuan ini melengkapi penelitian yang telah dilakukan oleh Devi (2018) yang menyatakan bahwa pertumbuhan ekonomi memiliki korelasi dengan disparitas wilayah di Kabupaten Sleman. Selain itu, meskipun dalam penelitian sebelumnya mengungkapkan tidak adanya pengaruh yang signifikan antara faktor sarana kesehatan terhadap disparitas wilayah dalam lingkup yang lebih luas, yaitu Daerah Istimewa Yogyakarta (Rachmawati, 2017), namun penelitian ini mengungkapkan bahwa di lingkup Kabupaten Sleman sendiri faktor sarana kesehatan memiliki pengaruh terhadap disparitas wilayah.

Berdasarkan temuan tersebut, pemerataan jumlah fasilitas kesehatan perlu menjadi perhatian pemerintah daerah, khususnya Pemerintah Kabupaten Sleman, mengingat faktor tersebut merupakan salah satu penyebab terjadinya disparitas wilayah. Fasilitas kesehatan merupakan infrastruktur sosial yang cukup mendasar untuk memenuhi kebutuhan dasar dan menjamin hak-hak dasar penduduk dalam hal layanan kesehatan. Selain perhatian pada fasilitas kesehatan, pemerintah daerah juga perlu mendorong potensi sektor unggulan sesuai dengan karakteristik wilayahnya dalam rangka mengurangi ketimpangan yang terjadi antara kecamatan-kecamatan yang relatif tertinggal dengan kecamatankecamatan yang cenderung mengalami perkembangan yang cepat dan mengarah ke wilayah dengan ciri-ciri perkotaan.

\section{DAFTAR PUSTAKA}

Agusta, Ivanovich.(2014). Ketimpangan Wilayah dan Kebijakan Penanggulangan di Indonesia: Kajian Isu Strategis, Historis, dan Paradigmatis Sejak Pra Kolonial. Jakarta: Yayasan Pustaka Obor Indonesia.

Azwar, et.al. (2013). Economic Growth Disparity among the Regions in Aceh, Indonesia. Aceh International Journal of Social Sciences, 2 (1): 21 - 31.

Badan Pusat Statistik. (2018). Tinjauan Regional Berdasarkan PDRB Kabupaten/Kota 2013-2017 Puau Jawa dan Bali Buku 2. Jakarta : Badan Pusat Statistik.

Baransano, M.A., et.al. (2016). Analysis of Factors Affecting Regional Development Disparity in the Province of West Papua. Journal of Economics and Development Studies. Vol. 4, No. 2, pp. 115-128. 
Darzal. (2016). Analisis Disparitas Pendapatan dan Faktor-Faktor yang Mempengaruhinya di Provinsi Jambi. Jurnal Perspektif Pembiayaan dan Pembangunan Daerah. Vol. 4 No. 2, Oktober-Desember 2016.

Devi, M.K.(2018). Struktur Ekonomi dan Disparitas Wilayah Kabupaten Sleman. Jurnal Kurvatek, Vol.03.No.1, April 2018,pp.91-99.

Kutscherauer, A.,et.al.(2010). Regional Disparities: Disparities in Country Regional Development-Concept,Theory, Identifiation, and Assessment. Ostrava : Faculty of Economics VŠB-Technical University of Ostrava.

Muta'ali, L. (2015). Teknik Analisis Regional untuk Perencanaan Wilayah, Tata Ruang dan Lingkungan. Yogyakarta : Badan Penerbit Fakultas Geografi Universitas Gadjah Mada.

Pratiwi, N.N., (2011). Disparitas Wilayah Antar Kecamatan di Kabupaten Malang. Tesis: Universitas Gadjah Mada.

Rachmawati, Annisa. (2017). Faktor-faktor yang Mempengaruhi Disparitas Pembangunan di DIY. Tugas Akhir. Universitas Gadjah Mada.

Rahman, A. (2009). Analisis Disparitas Pembangunan Antar Wilayah di Kabupaten Sambas. Tesis : Sekolah Pasca Sarjana Institut Pertanian Bogor.

Rustiadi, Ernan dkk. (2011). Perencanaan dan Pengembangan Wilayah. Jakarta: Yayasan Pustaka Obor Indonesia.

Sjafrizal. (2008). Ekonomi Regional Teori dan Aplikasi. Padang : Baduose Media.

Todaro, Michael P. (2000). Pembangunan Ekonomi di Dunia Ketiga. (Ed.VII). Jakarta: Erlangga.

Wang, Fei. (2016). Analysis on the Regional Disparity in China and the Influential Factors. American International Journal of Humanities and Social Science. Vol. 2, No. 4, pp. 94-104. 